\title{
The Development of the Political System in Afghanistan: Current Perspective in the Context of National Consensus-Building
}

\author{
Amini Abdul Rahman ${ }^{1}$, Camara Sidy ${ }^{1}$, Manopov Mukhammadsolekh Musoevich ${ }^{1} \&$ Shir Aqa Njeebullah ${ }^{1}$ \\ ${ }^{1}$ RUDN University, Russia \\ Correspondence: Amini Abdul Rahman, RUDN University, Russia. Email: amini.ab@yandex.ru
}

Received: December 3, 2018

Accepted: December 28, 2018 Online Published: January 18, 2019

doi:10.5539/jpl.v12n1p1

URL: https://doi.org/10.5539/jpl.v12n1p1

\begin{abstract}
The relevance of the topic is due to the fact that at present the political system of Afghanistan requires fundamental changes: the political situation in the country continues to be complex and tense, and the tendency to aggravate the situation in the country is stable: terrorism, drug crime and corruption are common threats to both Afghanistan and the entire world community. Therefore, the search of the current perspective of the development of the political system of Afghanistan is the key factor to resolve this situation. Afghanistan continues to be a place of conflict between the interests of world and regional powers: the advantageous geopolitical and strategic location of Afghanistan makes it a key region in ensuring the stability of the military and political situation in the entire Central Asian region and gives it the opportunity to play an important role in economic, political and cultural interaction between the countries of the region. The purpose of the study is to consider the current perspective of the political system of Afghanistan. The article is devoted to the state of the modern political system of Afghanistan and the search for ways of its development and transformation. The current problems and ways of development of the political system of Afghanistan through the introduction of federalization and secularization are considered in detail. The author pays special attention to the fact that there are a lot of options for the development and transformation of the political system of Afghanistan, but on the way of their implementation in this country there are many problems.
\end{abstract}

Keywords: Afghanistan, political system of Afghanistan, development of Afghanistan, terrorism in Afghanistan, a secular state

\section{Introduction}

The politics of Afghanistan consists of the council of ministers, provincial governors and the national assembly, with a president serving as the head of stateThe relevance of the research topic is due to the fact that today there is clearly a crisis in the political system of Afghanistan, which has no military solution, the only possibility of resolving political problems in Afghanistan is the transformation of the political system in the country, the achievement of General Afghan agreement by all possible means with active international assistance. By 2010, nine years after the events of 11 September 2001 (9/11), the Afghan state appears to be characterized by a centralization of power. The situation is similarto that faced by the Soviets in 1987, in that the state is fiscally unsustainable and the government is only able to function in cities. 1 Moreover, the state is run by a political elite whose objectives seem diametrically opposed to those of the international community Like the Soviets halfway through their ten-year engagement in the 1980s, the inter-national community, struggling to extricate itself from its nearly decade-long engagement in Afghanistan and faced with a steady deterioration in security since 20052006 , is starting to focus on expensive militaristic 'stopgap' measures. These have been characterized by Kipping. They are also a desperate attempt to shore up the state security apparatus, and include the establishment of militias whose loyalty is questionable.

Afghanistan continues to be a place of conflict between the interests of world and regional powers: the advantageous geopolitical and strategic location of Afghanistan makes it a key region in ensuring the stability of the military and political situation in the entire Central Asian region and gives it the opportunity to play an important role in economic, political and cultural interaction between the countries of the region.

The situation in Afghanistan requires the resolution of numerous conflicts in the country. 


\section{Methods}

The article uses the following main categories of political science: political system, political institutions, political sphere, threats, politics, terrorism. The used scientific concepts do not contradict the system of principles, methods and methods of theoretical knowledge, emphasize the beginning of practical comprehension of the object of political science, reflect the important laws of the formation of modern research approaches (systemic, institutional, neo-institutional and comparative approaches) and their features, show the device of practical impact and the ratio of theoretical and applied aspects of political activity. The applied categories reinforce the author's argument. The methods used in the study are adequate. Among them are: comparative analysis, structural and functional analysis, sociological analysis, observation, included observation, extrapolation. The methods and approaches used helped to achieve the goal and solve the block of the stated tasks. The theoretical basis of the study is a comprehensive set of scientific concepts related to the understanding of the specifics of tangible and intangible assets as political resources. Among them are Grishin O. E. (the political system), Aleinikov S. M., Buryanov S. A, Barry A. Kosmin, Ariela Keysar (secular state, secularism \& secularity), Anufrieva S.V., Anufrieva L.A. Weiss M., Hassan H. (modern terrorism and Islamic state), etc.

selecting samples has been done by generally accepted statistical methods (e.g., probabilistic methods that can provide estimates of sampling error). Thus, any use of nonprobability sampling methods (e.g., cut-off or model-based samples) must be justified statistically and be able to measure estimation error. In this study, random sampling and design-based inference are supplemented by other statistical methods, such as model-assisted sampling and model-based sampling. Despite of other surveys which they have substantial amounts of nonresponse, in this article proposed samples are initially chosen with known probabilities, the nonresponse mechanisms are unknown.

\section{Results}

Let us consider the main characteristics of the political system in Afghanistan.

The state-political structure of Afghanistan at the present stage is a system of political, legal, administrative, economic and social relations in Afghanistan, which are established by the Constitution of Afghanistan, adopted in 2004 (Constitution of Afganistan, 2004), as well as the structure of this state, due to the socio-economic development of society and the ratio of political forces in this country.

Afghanistan is a unitary state by form of government and a presidential Republic by form of government. The government of Afghanistan consists of a President, two vice-presidents and a Parliament (National Assembly) consisting of two chambers: the Lower and the (Stepanova, 2012).

Afghanistan is a multinational state: ethnicity Afghanistan refers to a multiethnic society with the constituent peoples - Pashtuns, who make up about $40 \%$ of the population.

According to the current political system in Afghanistan, the following conclusions can be drawn:

- One of the main problems in Afghanistan is the constantly escalating confrontation between militants of the Islamic movement Taliban, which originated in 1994, and the government of the state. In recent years Afghanistan has not only strengthened the position of the Taliban, but also a unit of the "Islamic State", which is fighting and the government of Afghanistan with the support of the coalition and the Taliban.

- According to estimates, currently the Islamic movement Taliban controls about $13 \%$ of the areas of Afghanistan, almost half of the territory of the state, the Taliban operate openly, conducting active hostilities against the government of Afghanistan. About 37\% of Afghanistan's districts are under government control.

- The current situation in Afghanistan can be described as a rather complex and multilateral internal conflict. This conflict was caused by the problems in the country (religious contradictions, weakness of the current government, non-observance of human rights) and external factors (interests and actions of foreign countries involved in the Afghan conflict).

- The main condition for the successful resolution of the Afghan conflict is to smooth ethnic and religious contradictions, ensure the rule of law and respect for human rights, and successfully adapt existing cultural and religious systems to each other.

- National reconciliation cannot be achieved through military methods that have proven to be limited and ineffective. The basis for national reconciliation should be a dialogue that includes the views of all stakeholders. It should be noted here that the government of Afghanistan has repeatedly expressed its readiness for dialogue, including with representatives of the Islamic Taliban movement, however, according to the Taliban, the government of Afghanistan is a "puppet", and they would like to enter into a dialogue 
directly with their masters - the United States of America.

- The lack of an economic basis for the country's independent development increases the dependence of the Afghan authorities on the assistance of foreign donors, most of whom are trying to ensure the realization of their military, political and economic interests in the region (Korstanje, 2013).

The main factors that have a negative impact on the development of the situation in Afghanistan are currently:

- Recently the situation in Afghanistan has escalated dramatically: almost every day there are clashes of militants, in which many police, military and national security officers of Afghanistan are killed. Along with the fighting between the government of Afghanistan and the Taliban, the situation is negatively affected by the presence of Islamic state terrorists in the country, with whom both sides of the conflict are fighting

- The ongoing conflict and fighting on all sides eventually lead to new victims not only among the combatants, but also among the civilian population. Thus, according to official United Nations data, 149 civilians were killed by air strikes in Afghanistan in the first half of 2018, another 204 people were injured of varying severity, with about $45 \%$ of civilian casualties accounted for the attacks of the international coalition forces

- In the country there has been no progress in establishing national unity.

- The security forces of Afghanistan are unable to provide security in the country on their own.

- In a number of regions of the country (mainly southern Afghanistan - Helmand province, Kandahar, etc.) there is a high involvement of the state population in criminal business, primarily in the production and distribution of drugs.

In these circumstances the prospect of a peaceful settlement and stabilization of the situation in Afghanistan largely depends on the ability of the current government to establish a dialogue with the Taliban, as well as to lay the political and economic foundation for the further independent development of Afghanistan (Korstanje, 2015).

Another reason for the conflicts in Afghanistan is dissatisfaction with the interests of ethnic groups, economic and political inequality between them. The main obstacle to the stabilization of society is the extremely low-income population, which for this reason enters into terrorist groups, it is strongly influenced by religious ideology.

At present there is an acute struggle in Afghanistan for public office among representatives of various ethnic groups. The main state positions in Afghanistan are now occupied by Pashtuns and Tajiks. If the interests of all ethnic groups in Afghanistan are taken into account, the influx of this category of population into international terrorist organizations may decrease.

On the basis of these problems, we consider the main ways of development of the political system of Afghanistan.

Among the possible ways to develop the political system of Afghanistan is the introduction of the model of ethno - federalism in the state structure of the country through the introduction of representatives of small ethnic groups in the Afghan authorities.

The analysis of the state-political structure of Afghanistan at the present stage showed that despite the formal completion of the process of distribution of power between the supporters of the current President of Afghanistan M. Ashraf Ghani (nationality - Pashtun) and the head of the Executive Council (nationality - Tajik), the efficiency of the new formed government continues to be low (Korstanje, 2015). Therefore, in Afghanistan, it is necessary to institutionalize both the interests of the regions as a whole and the interests of ethnic groups separately in the state authorities.

Tolerance and partnership can succeed in addressing the growing economic gap between rich and poor, familiar to the West but not cultivated or replicated in the East. This growing gap in economic conditions between the poor East and the rich West leads to increased anger, support for terrorism by the poorest segments of the population, the spread of drug trafficking and its consequences, etc.

In the future, this may lay the foundations of a mechanism whose task will be to reduce interreligious tension in the country and in the region, promote spirituality, peace and tolerance. This political and legal direction predetermines the presence of special methods of implementation of the negotiation process, which determine the peaceful settlement of the beginning conflicts and confrontations on a democratic basis.

National accord in Afghanistan is a necessary condition for the formation and strengthening of a truce.

The second aspect of the development of Afghanistan's political system is the introduction of the institution of secularism. 
Secularism of the state is an important concept in the political system of the state, especially in the sphere of relations between the state and religious associations. Today, it is important for any democratic state governed by the rule of law not to allow the dominant role of religion and clergy in the social, political and cultural life of society. This is especially true for countries where religion has a strong influence on the life of society and there are ethnic and religious contradictions, which can be safely attributed to Afghanistan. Afghanistan is one of the Islamic States in which religious norms and laws are most clearly manifested.

The principle of secularism of the state is one of the fundamental principles of construction and functioning of the modern legal state in most countries of the world (Ponkin, 2013). However, there is no precise universally accepted definition of a secular state in the international or national law of the countries of the world. Each country builds its relations with religion depending on its own historical experience and the civil society existing in the country.

A secular state is a state where there is no official state religion, and none of the religious teachings is recognized as preferable or obligatory. In a secular state, religion has no right to influence the spheres of state activity: the state system, the activities of state bodies and their officials, the system of state formations, etc (Shandybina, 2015).

A modern secular state is a state whose norms and ideals are determined regardless of attitude to religion, ideology or other system of knowledge, but based on their historical role in the life of a particular people (Shchipkov, 2017).

Secularism of the state implies a fundamental difference between the goals, objectives, functions and spheres of activity of the state and religious associations. The secular nature of the state does not mean or imply the complete removal of the state from this sphere of public relations or the isolation of the state and civil society institutions from religious associations. The essence of secularism of the state - is voluntary in the adoption and defense of worldview, a ban on the imposition of worldviews and ideologies (Ponkin, 2013).

There are the following features of the modern secular state:

- no religion may be established as state or compulsory,

- all religions must be recognized as equal,

- all religious associations should be separated from the state and equal among themselves,

- the state should not interfere in the Affairs of religious associations and should not entrust them with state functions,

- the state should guarantee the free activity of religious associations subject to their compliance with the Constitution and laws, and religious associations should not interfere in the work of state bodies and engage in political activities (Shakhov, 2014).

However there is no universal internationally unified "model" of secularism of the state - a certain list of the properties of secularism of the state. Therefore the proclamation of the state as secular is primarily a political Declaration of the state's neutrality with regard to the religious sphere, i.e., in the exercise of its powers, the state must remain neutral and impartial, but it must take the necessary measures to smooth out emerging crises, reconcile conflicting interests and ensure religious tolerance and peace.

Secularism of the state also means freedom of thought and readiness to introduce into the life of society all new and useful, to promote scientific and technological progress.

In the modern sense the secular state is a system of governance based on equal treatment of all social groups, taking into account the interests of the whole society, of which the state is a part. This system of government ensures respect for the principles of the Constitution and the equal enforcement of laws by all parts of society and citizens.

Consider the prospects for the introduction of a secular state on the example of Afghanistan.

According to article 2 of the Constitution of Afghanistan, the religion of Afghanistan is the sacred religion of Islam. More than $99 \%$ of the Afghan population is Muslim. About $80 \%$ are Sunni (Hanafi), and $18 \%$ of the Shiite tide. Islam on the territory of modern Afghanistan has spread in the VIII-XI centuries and still continues to play a significant role in all spheres of life (Constitution of Afganistan, 2004).

As part of the classification of countries in relation to their religion Afghanistan is a clerical state, since Islam in the country officially has the status of a state religion and occupies a privileged position in relation to other religions (Kapinos, 2009). 
The entire national legal system of Afghanistan is also determined by the clerical nature of the state. According to article 3 of the Constitution of Afghanistan, no law that contradicts the sacred religion of Islam and the values established by the Constitution of Afghanistan can be adopted in Afghanistan. The legal system of Afghanistan belongs to the Muslim legal family, the Sharia has an impact on all branches of law. This is due to the fact that Islam regulates all aspects of society, the division into "secular" and "religious" components of society is virtually absent (Constitution of Afganistan, 2004).

Other religions make about $0,4 \%$ - in Afghanistan representatives of the following religions are also represented: Christians (about 30 thousand people), Hindus, Bahai, Sikhs, Zoroastrians, but they make the small population. According to the Constitution of Afghanistan, followers of other religions are free in religion and observe their religious rites within the framework of the law (Constitution of Afganistan, 2004). However, from the standpoint of Islamic law, conversion to another faith is a criminal offense, so the situation of Afghan Christians remains difficult.

The role of Islam and the influence of this religion on all spheres of society in Afghanistan are very great. Islam is the only religion in the world that regulates not only the actions of believers in the mosque, but also has a significant impact on all spheres of society and the population of Afghanistan. The religious beliefs of Afghans are very strong. Islam is a religion that subjugates the lives of Muslims from birth to death. For centuries, the essence of Afghan identity has been shaped and nourished by Islam. The whole life of a Muslim is subject to the dogmas of a systematic set of Muslim laws (Sharia). Islam for a Muslim is a system of values and a set of laws governing his behavior. Islam for the majority of the population of Afghanistan is an object of universal recognition and support, an institution recognized and legitimate by all. Islam in Afghanistan is not only a religion, it is a way of life and thoughts, the core of the whole civilization.

The Muslim clergy also enjoy great authority in Afghanistan. Thus in the mountain villages, where up to $98 \%$ of the population is illiterate, the Mullah plays a significant role, it is the bearer of Sharia law, opinions and sentiments of the population.

Consider the interaction between Islam and the ongoing armed conflict in Afghanistan. The intra-Afghan conflict (the civil war in Afghanistan) is a series of armed conflicts in the struggle for political power in Afghanistan. Armed conflicts in the struggle for political power in Afghanistan began in April 1978, when, as a result of a military coup called the April revolution, the people's democratic party of Afghanistan came to power.

The traditional Afghan method of warfare before and after the establishment of Islam was based on the rule of victory or death. It was perfectly suited to the pragmatic nature of the Afghans. However, this rule was contrary to the requirements of the new form of warfare prescribed by the principles of Islam. The new ways of warfare established by Islam were more difficult for Afghans and sometimes ran counter to the existing rules of engagement. The new rules regulate issues such as "collateral damage" inflicted on civilians that included limitations on the attack on wounded opponents, according to Islamic rules the wounded and the prisoners, it was impossible to cause harm.

Today's attempt to introduce modern western-style democracy is almost impossible to realize in Afghanistan after almost 40 years of political, social and religious conflict. The attempt to realize this is taking place against the backdrop of an ongoing and growing conflict that is tearing apart Afghan society and squeezing the Islamic faith of Afghans into an increasingly fundamentalist form. Afghans find themselves in a grip that forces them to change their way of life, to give up control over their territory, to deal with the dynamic interaction of Islam and armed conflict within the framework of the development of society.

The enormous influence of Islam in all spheres of society is also widely reflected in the phenomenon of international terrorism. Modern international terrorism is as a rule Islamist (Jin, 2017).

The causes of international terrorism are global inequality and widespread poverty in the third world. The presence in the third world of a large number of people who are strongly influenced by religious ideology and the extremely low standard of living of this population, lead to the fact that for them financially attractive offers of international terrorist organizations become a decisive factor for joining this organization and in some cases sending to Syria and Iraq.

Another reason for such a massive development of international terrorism is the absence of a secular state, a full - fledged system of education based on human values. People involved in terrorism see the world differently, they have grown up in a system where there are no human values.

In Afghanistan, there is a clear increase in the influence of radical religious parties and movements, primarily the Islamist Taliban movement, the international terrorist organization Islamic state (IG) and Al-Qaeda. By reason of 
illiteracy, poverty, and a strong exposure to the influence of the religion of Islam the population of Afghanistan is entering in a terrorist organization, thereby contributing to the increase in political tension in the country.

With regard to the influence of religion on the political life of Afghanistan, it can be noted that since the adoption of the Constitution and the law on political parties in 2004, the process of formation and registration of political parties has accelerated significantly. There are currently more than 85 parties in Afghanistan. All parties in Afghanistan are focused primarily on religious values. Modern political parties in Afghanistan differ in ideological terms, which is expressed in relation to the ongoing reforms and the foreign presence. Most parties were created to unite the population of the country to confront external forces during conflicts. Almost all parties were created primarily for military purposes, which is contrary to the modern Constitution, and they differ mainly in the degree of radicalism. In general the party system of Afghanistan is going through a transitional stage of formation. In Afghanistan the influence of Islam on all aspects of society and the state as a whole is enormous.

Thus the principle of secularism is a fundamentally new category for Afghanistan. His example clearly shows the complexity of the implementation of the principles of secularism of the state in the existing political system. According to some historians, in the early 50-60s of the twentieth century, Afghanistan was a secular state, but then the imposition of Islam nullified all initiatives.

One of the serious external obstacles to the secularism of the state of Afghanistan is that this country is one of the key States for the implementation of Asian geopolitics of the world's largest players for many decades, Afghanistan remains a place of conflict of interests of world and regional powers. Despite all the efforts of the Afghan government in different periods, the emergence of a secular state with a developed economy, industry and science, at a key point in the Asian region, categorically does not suit the world's major political players.

At the same time there are significant internal obstacles to the implementation of the principles of secularism of the state. The current situation in Afghanistan can be described as a rather complex and multifaceted internal conflict. This conflict was caused by problems within the country (religious contradictions, weakness of the current government, non-observance of human rights) and external factors (interests and actions of foreign countries involved in the Afghan conflict) (Korstanje, 2015).

Currently cultural and religious systems are being adapted in Afghanistan and this adaptation is not always adequate to new technologies, new social relations, specific legal positions of the countries concerned.

In Afghanistan, the problem of peaceful coexistence and constructive interaction between religions, peoples, state and government on the basis of international law is becoming increasingly acute. The main cause of conflicts is dissatisfaction with the interests of ethnic groups, economic and political inequality between them. The main obstacle to the stabilization of Afghan society is the population, which is strongly influenced by religious ideology with an extremely low standard of living, which joins opposition groups.

The main condition for the successful resolution of these conflicts - the creation of a secular state, smoothing ethnic and religious contradictions, ensuring the rule of law and respect for human rights, the successful adaptation of existing cultural and religious systems to each other.

For the introduction of a secular state in Afghanistan at the state level, it is necessary to carry out reforms that should be aimed at the creation of a secular state, in the country it is necessary to consolidate the separation of politics from religion at the legislative level.

The establishment of the institution of secularism in the political system of Afghanistan could be one of the main achievements of social and political transformation.

This requires the following activities:

- Islam in the country should be limited at the legislative level to the sphere of personal life,

- the role of Islam in the country should be minimized,

- the parties of Afghanistan should not address various issues related to religion in their discussions,

- the people of Afghanistan should not make a choice in their political preferences, given the degree of religious commitment of the party.

If we consider the secularism of the state as a willingness to implement in the life of society all new and useful, to promote scientific and technological progress, it is necessary to implement the following reforms in Afghanistan:

- increase of employment, creation of jobs in all spheres of society, 
- increase in the minimum wage,

- birth control,

- prohibition of the practice of closely related marriages, introduction of eugenic laws,

- increasing the number of educational institutions, the unification of all educational bodies under a single leadership,

- fight against corruption,

- tight border controls to maintain security in the country,

- adoption of new criminal and civil codes on the European model, etc.

Given the existence of ethnic and religious contradictions in Afghanistan, all the principles and functions of a secular state in the country should be fully implemented, without providing advantages and privileges in state policy with regard to any denominations or infringement of their rights. The very fact of the existence of religion in society requires the state to develop and implement a sound and reasonable policy towards it.

Thus the secular nature of the state of Afghanistan is necessary for the joint comfortable existence of religion, society and the civilian population in the country. The introduction of new mechanisms of interaction between them can be a powerful incentive for the development of Afghanistan.

The secularism of the state in Afghanistan today is a necessary condition for the peaceful and comfortable coexistence of religion, society and the civilian population of the country. The development of civilized forms and mechanisms of interaction between the state, religions and society is an urgent task, which can create new incentives for the development of Afghanistan.

Another aspect of the development of Afghanistan's political system is the involvement of the international community to reduce significant financial support from the state sponsors of terrorism, which, according to the official position of the US state Department, support acts of international terrorism. As of January 13, 2016, Iran, Sudan and Syria are officially on this list.

The recognition of the country as a sponsor of terrorism provides for the imposition of certain economic and political sanctions on this country by the United States of America.

In addition to these countries, the financial support of international terrorism include a number of other countries: Saudi Arabia, UAE, Qatar, Oman and Bahrain, etc.

Today Saudi Arabia is an informal center of the Islamic world, where the main shrines of all Muslims - Mecca and Kaaba-are located.

Qatar has recently been accused several times by various media, experts and political figures of different countries of sponsoring and fully supporting Islamist terrorist organizations: Al-Qaeda, Taliban, Islamic State, Muslim Brotherhood, Hamas, etc.

The elimination of support from state sponsors of terrorism could significantly undermine the capacity of terrorist organizations. Therefore, one way to reduce the potential of international terrorism is to impose sanctions and restrictions on countries that provide financial support to international terrorism.

Thus in June 2017 there was a Qatari diplomatic crisis, which was expressed in the fact that several countries, one after another - Bahrain, Saudi Arabia, Egypt, the UAE, Yemen, Libya, Mauritania, Maldives, Comoros, Mauritius - broke off relations with Qatar. The reason for this was Qatar's ties with terrorist organizations, Qatar's interference in the internal Affairs of the countries of the region and the spread of the ideology of terrorist organizations "Al-Qaeda", "Islamic State" and "Muslim Brotherhood". Jordan has reduced its diplomatic presence in Qatar. Saudi Arabia, Bahrain and the UAE demanded that Qatari nationals leave their countries within 14 days, and demanded that their subjects leave Qatar. In addition, neighboring countries have established a complete blockade of Qatar. Qatar's participation in the operation against the Houthis in the civil war in Yemen was also stopped.

In order to effectively combat terrorism it is necessary to reliably cut off the sources of its financing, as required by United Nations security Council resolutions and international standards of the financial action Task force on money laundering (FATF). Therefore it is necessary to pay increased attention to the development of international cooperation in the field of combating money laundering and the financing of terrorism.

After solving the current urgent problems in the political system of Afghanistan, it is possible to introduce the basic ideas of transhumanism and eugenics into the development of society by analogy with Europe. 
The ideology of transhumanism is associated with the use of science and technology to improve the mental and physiological capabilities of man and eliminate undesirable aspects of his existence, such as pain, poverty, disease, aging, death, etc.

The formation of transhumanist parties in Europe and around the world began in early 2015. In this context transhumanism was an international movement that claimed that with the help of scientific and technological progress it is possible to achieve significant changes in a person's life: to significantly enhance his mental, physical and psychological capabilities, to reduce disease, aging, to maximize life (Chetverikova, 2018).

Today the interpretation of transhumanism is as follows-a rational worldview, which is based on the understanding of the achievements and prospects of science, which recognizes the possibility and need for fundamental changes in the human situation with the help of advanced technologies to reduce suffering, aging and death and significantly enhance its physical, mental and psychological capabilities (Chetverikova, 2018).

Currently transhumanist movements are gaining momentum around the world. In Russia, the Russian Transhumanist Movement (RTD) promotes the ideas of scientific transhumanism, as well as new research and technologies that will allow people to surpass the "natural" limits of their body, mind and life (Russian Transhumanist Movement, 2018).

Since 2011 the strategic public movement "Russia-2045" has been operating in Russia, which promotes the ideas of transhumanism and advocates for human development, including through the acceleration of technological progress and the introduction of modern technologies, resistance to the growth of consumption in society and the exploitation of the environment (The strategic social movement Russia, 2018).

The main purpose of this worldview is the continuous improvement of human, which is based on the latest achievements of scientific and technological progress. To achieve this goal, it is necessary:

- to support technical development in every possible way,

- to study and implement the achievements of science and technology,

- in time to prevent problems that may interfere with the implementation of these achievements,

- to expand the freedom of each individual using scientific and technological achievements,

- as much as possible to delay the aging and death of man,

- resist the teachings and organizations whose goals are at odds with the ideas of transhumanism,

- to resist state measures that limit advanced scientific research and prohibit the use of new technologies (prohibitions on human cloning, psychotropic drugs, embryonic stem cells, etc.) (Chetverikova, 2018).

Transhumanists support the development of new technologies: nanotechnology, biotechnology, information technology, developments in the field of artificial intelligence, loading consciousness into computer memory, cryonics and other technologies that can bring the abilities and capabilities of a person to a new, previously unattainable level.

Eugenics has its roots in people's desire to maximize their productivity. First of all, eugenics is a science that studies artificial selection, the main object of which is a person.

Control over this selection is carried out in two ways: positive eugenics stimulates marriages, as a result of which children are born with popular traits for society, negative eugenics prohibits the birth of children with developmental defects or traits that are undesirable for society, with the help of birth control methods such as screening, genetic tests and ultrasound diagnostics. Thus, the goal of positive eugenics is to promote the birth rate of society with valuable characteristics for society (absence of hereditary diseases, good physical training and high intelligence). The purpose of negative eugenics is to prohibit the birth rate of children with hereditary defects, or those who are considered physically or mentally disabled in society.

However if we do not go to extremes and highlight the rational grain in these two new worldviews, it can be noted that both transhumanism and eugenics, with the right approach, can be factors in the development of Afghan society. They can contribute to:

- to reduce crime,

- poverty reduction,

- the reduction of human suffering,

- the disappearance of such a thing as the death penalty, 
- reduction of diseases, primarily cancer, due to new advanced technologies (modern gerontology, nano - and biotechnology, etc.).),

- significant strengthening of intellectual and creative abilities of the person and society as a whole (including by means of cognitive technologies, etc.).),

creation of an abundance of resources for each person (due to molecular nanotechnology, etc.).

\section{Discussion}

Thus there are quite a lot of options for the development and transformation of the political system of Afghanistan, but there are many problems on the way to their implementation in this country.

One of the main problems in Afghanistan remains the ever-escalating confrontation between militants of the Islamic movement "Taliban" and the government of the country. It is estimated that the Taliban Islamic movement currently controls about $13 \%$ of Afghanistan's areas, and that almost half of the state's territory is open to the Taliban, with active fighting against the government of Afghanistan.

The basis for national reconciliation should be a dialogue that includes the views of all stakeholders. However the Taliban are ready to hold this dialogue not with the government of the state, but with those under whose real control (the USA).

At the same time it is necessary to involve the international community in order to reduce significant financial support from the state sponsors of terrorism.

A number of researchers agree that it is necessary to introduce the Institute of secularism in the country. However, there are significant internal obstacles to the implementation of the principles of secularism of the state. The current situation in Afghanistan can be described as a rather complex and multifaceted internal conflict. This conflict was caused by the problems in the country (religious contradictions, weakness of the current government, non-observance of human rights) and external factors (interests and actions of foreign countries involved in the Afghan conflict) (Pinker, 2011).

As for the introduction of such progressive worldviews as transhumanism and eugenics, these views have their supporters and opponents. It is necessary to allocate rational grain in these worldviews, and to introduce them after the solution of actual problems.

\section{Conclusion}

Thus in this article the ways of development of the political system of Afghanistan were considered. First of all it is necessary to focus on building a political dialogue with the Taliban, to involve the international community in the elimination of support from the state sponsors of terrorism, which can significantly undermine the capabilities of terrorist organizations in Afghanistan.

In order to effectively combat terrorism, it is necessary to reliably cut off its sources of financing, and therefore it is necessary to pay increased attention to the development of international cooperation in combating money-laundering and the financing of terrorism.

The secularism of the state in Afghanistan today is a necessary condition for the peaceful and comfortable coexistence of religion, society and the civilian population of the country. The development of civilized forms and mechanisms of interaction between the state, religions and society is an urgent task, which can create new incentives for the development of Afghanistan.

In the future the country needs to implement the principles of federalization and secularism of the state. And after solving all these urgent problems partly introduce the principles of transhumanism and eugenics.

\section{References}

Acemoglu, D., \& Robinson, J. A. (2013). Why nations fail: The origins of power, prosperity, and poverty. Broadway Business.

Campos, N. F., \& Nugent, J. B. (2002). Who is afraid of political instability? Journal of Development Economics, 67(1), 157-172. https://doi.org/10.1016/S0304-3878(01)00181-X

Chetverikova, O. N. (2018). Spirit and goals of transhumanism. Moscow: Publisher Gennady Markelov, 160.

Constitution of Afganistan. (2004). Kabul.

Durlauf, S. N., Johnson, P. A., \& Temple, J. R. (2005). Growth econometrics. Handbook of economic growth, 1, 555-677. https://doi.org/10.1016/S1574-0684(05)01008-7 
Greif, A. (2006). Institutions and the path to the modern economy: Lessons from medieval trade. Cambridge University Press. https://doi.org/10.1017/CBO9780511791307

Jin, Y. (2017). International terrorism. The main ways of combating international terrorism at the present stage. Young scientist, 20, 389-392.

Kapinos, R. (2009). Economic ideas of the Koran and the practice of modern Islam. World economy and international relations, 3, 101.

Korstanje, M. E. (2013). Preemption and terrorism. When the future governs. Cultura, 10(1), $167-184$. https://doi.org/10.5840/cultura20131019

Korstanje, M. E. (2015). Acemoglu, Daron \& James R. Robinson. Why Nations Fail: the origins of power, prosperity and poverty. Journal of International and Global Studies, 6(2), 97-101.

Pinker, S. (2008). The stupidity of dignity. The new republic, 28.

Pinker, S. (2011). The better angels of our nature: The decline of violence in history and its causes. Penguin uk.

Ponkin, I. V. (2013). Secularism of the state: on the question of determining the legal content of the concept. Education, (3).

Shakhov, M. O. (2014). To the question on the legal ratio of the principle of secularism of the state and of the principle of separation of religious associations. Religion and law, (2).

Shandybina, M. (2015). Russian model of secular state: expectations and reality. Public service, 4(96).

Shchipkov, A. (2017). How to understand secularity. Retrieved October 19, 2017, from http://pravoslavnye.ru/opp/2017/sentyabr/11/kak_nam_ponimat_svetskost_gosudarstva/

Stepanova, E. A. (2012). Afghanistan: prospects for a political settlement. Pathways to peace and security, 1(42), 18-33.

The strategic social movement Russia 2045. (2018). Retrieved July 31, 2018, from http://2045.ru

\section{Copyrights}

Copyright for this article is retained by the author(s), with first publication rights granted to the journal.

This is an open-access article distributed under the terms and conditions of the Creative Commons Attribution license (http://creativecommons.org/licenses/by/4.0/). 